\title{
Sir Joseph Barcroft, Cambridge placental and fetal research (1933-1966) and inter-generational Science
}

\author{
ROBERT BOYD ${ }^{1}$ and C.A. RICHARD BOYD*,2 \\ ${ }^{1}$ Maternal and Fetal Health Research Group, University of Manchester, St Mary's Hospital, UK and \\ ${ }^{2}$ Brasenose College, Oxford, UK
}

\begin{abstract}
The nature of Cambridge (UK) placental and fetal research in the middle third of the twentieth century is reviewed on the basis of published literature and personal recollection. Joseph Barcroft is a central figure who came to fetal research late in an extremely productive career which is briefly sketched. Contemporaneous Cambridge academics in the field included J.D. Boyd (the authors' father), J. Hammond, F.H.A. Marshall, R.A. McCance, J. Needham, A.S. Parkes and Elsie Widdowson. The then current Cambridge academic geography is explained and features of its scientific life such as funding, institutional structure and ethos, teaching and clinical duties, domestic and gender roles, and political context, including war and empire, are briefly considered. The testing of research findings against general principles and use of quantitative thinking are identified as important features. Intergenerational connections, often within individual families, are identified as a striking feature. The long-term impact of Cambridge work of this period; locally, in current trophoblast and feto-placental genetic research, in Oxford in probably influencing G.S. Dawes' research leadership, and internationally, especially through D.H. Barron, and through him to the Denver School, is considered. That human placental and embryological specimens collected by J.D. Boyd have received a new lease of life as the "Boyd Collection", including use by Allen Enders is noted. Mechanisms for the maintenance of scientific quality and productivity during the period, mainly through the scientist himself relying on an internalised sense of "obligation", are contrasted with those current in the UK and more widely; formal peerreview at frequent intervals, with subsequent allocation of short-term funding. The strengths and weaknesses of each are considered.
\end{abstract}

KEY WORDS: placental research, fetal research, Cambridge, Joseph Barcroft, J.D. Boyd

\section{Wimsatt: What do you think of Hansson's ideas?... \\ Enders R.K.: Probably my son should answer this. He has made a histochemical study... \\ Printed discussion following Enders R.K. \\ (Enders, 1956, page 127).}

According to Hans Krebs, analysis of the lives of Nobel Laureates, of which he was one, shows early and close working with a scientific mentor of high quality to be central to their future success (Krebs, 1967). A glance at scientific biographies or memoirs will confirm that such experience is the key factor in the early careers of most creative scientists. There are, however, other related elements which may correlate with such mentoring and nurturing which Krebs does not elaborate. Two are of general relevance; the third more individual, but perhaps commoner than is generally noted.
First, the financial context of research at a given period and the opportunity for professional advancement which may be more or less favourable to development of the next generation. Second, the institutional ethos characteristic of the Department, Campus or entire Institution in which a young scientist first spreads his or her wings. This ethos, positive or negative, transcends the individual mentor and, importantly, has a cultural history of its own. Both these relate to national attitudes to research. Is its support the duty of government, of charitable Foundations, of industry or of patrons? Is its quality maintained by the ethos of individual scientists and their desire to be well regarded by their peers or externally by departmental heads or by funding review?

Third, and more individually, just as the placenta is parent to the child, the same may be true of scientists, including placentologists. Allen Enders' early work on delayed implantation in the mink, providing evidence at the fine structural level of

*Address correspondence to: Richard Boyd. Brasenose College, Oxford OX1 4AJ, UK. Fax: +44-1865-272157. e-mail: studycenter@dpag.ox.ac.uk 


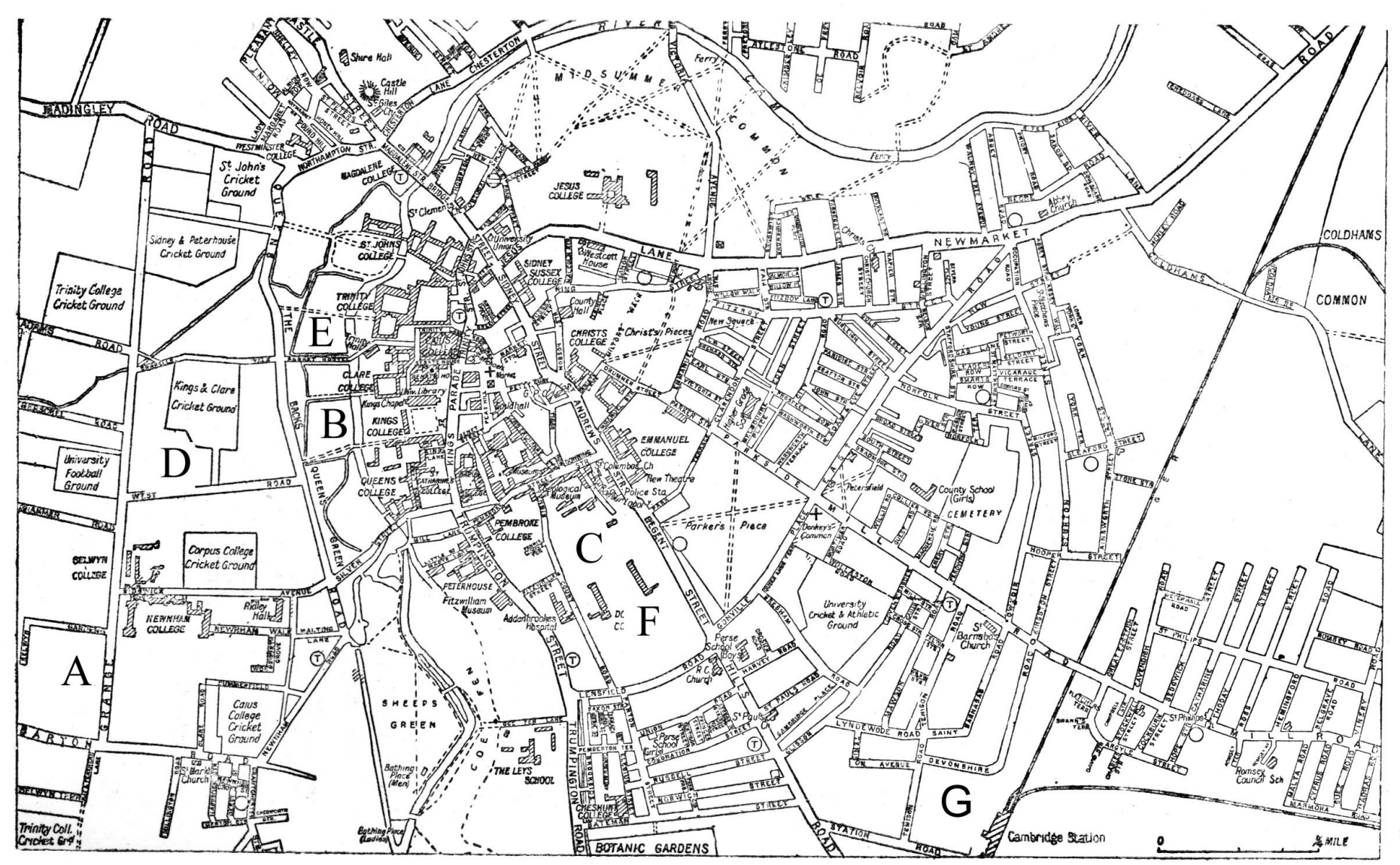

Fig. 1. Map of Cambridge in 1926 (Gray, 1926) including the site of Barcroft's home (A), college (B), lab (C); and Boyd's home (D), college (E) and lab (F). (G) The railway station.

diminished secretion by endometrial gland cells during the delay, was published jointly with his father (Enders etal., 1963). The same is true of others including Barcroft (see below) and indeed one of us (Boyd et al., 1968). ${ }^{1}$

Parent-related research networks can also play into the childhood experience of investigators to be. As an example we were, in the 1940s and 1950s, immersed in social life with scientific colleagues of our father's and especially their children in a world in which a distinction between work and relaxation was not obvious. Questioning as a 12 year old could lead to a morning dissecting a human fetus. Wartime exigencies in World War II, could lead to an invitation to live with a colleague away from the risk of bombing; in our case with Joseph Barcroft's grandchildren in the home of his son Henry, a son distinguished as a cardiovascular physiologist whose early published work was, again, joint with his father (Barcroft J \& Barcroft H, 1923).

Here we address the nature and interaction of Krebs' mentoring and of these three influences in Cambridge placental and fetal research (especially placental), around the middle of the 20th century drawing on a mixture of memory and data. We then briefly consider how far such influences are different today and what enduring legacy of the Cambridge School of that period there may be.

\section{Cambridge academic geography}

Cambridge, fifty miles north east of London, was in the 1930s a large market town with a celebrated university in which research and laboratory teaching in bioscience took place in independent but physically adjacent 'Departments'; in the nomenclature of the time, 'Preclinical Departments' or, occasionally, in semi-autonomous institutes e.g. the Molteno Institute mentioned below.

Departments were headed by long-serving disciplinary heads - 'the Professor'. (J. Barcroft was Professor of Physiology and head of Department, 1925-1937.) Non-laboratory teaching and much academic social life was focussed in the Colleges of which there were some 20 at that time (all except two for females being single-sex male; Barcroft's was Kings College). These were almost independent in governance and importantly were multidisciplinary. More widely, there were very strong links in most disciplines with colleagues in Oxford University, conveniently connected by railway via 'the Bletchley line' until 1964, and in biomedicine with London's twelve Teaching Hospitals which provided the 'clinical years' of education for Cambridge's medical students.

Research interests might be pursued individually or within a

\footnotetext{
1 Intergenerational examples at professorial level in Cambridge covering this period are several: in physiology, the Adrians (E.D. \& R.H), and the Matthews (B.H,C. \& P.B.C.); in physics, the Braggs (W.H. \&W.L.) and the Thomsons (J.J. \& G.P.); and, most notably, the Darwins e.g., amongst many references (Keynes, 2002).
} 
single discipline across geography. Interests at the boundaries of disciplines, as today, might, we infer, be fostered by meeting over a common research (or teaching) duty. Thus, when Joseph Barcroft's first fetal physiology paper was published in the Journal of Physiology, its Editorial Board had him as a member and also F.G. Hopkins (qv) \& F. Marshall (qv), both of whom already contributed directly or indirectly to this research area. Perhaps more than today, crossspeciality understanding was fostered by formal trans-disciplinary 'Clubs'. Barcroft had been president of the student Cambridge University Natural Science Club (Pepys, 1972) whose membership during its first hundred years included (of a group never larger than 22) 10 future Nobel laureates. From Physiology, these were E.D. Adrian, H.H. Dale, A.L. Hodgkin and A.F. Huxley; friendships made at such clubs were often continued throughout a career. More senior Cambridge biologists had the Ray Club, named after an $18^{\text {th }}$ century naturalist.

Krebs (op cit), who worked in Cambridge himself during part of our period, singled out as its leaders in bioscience in the early decades of

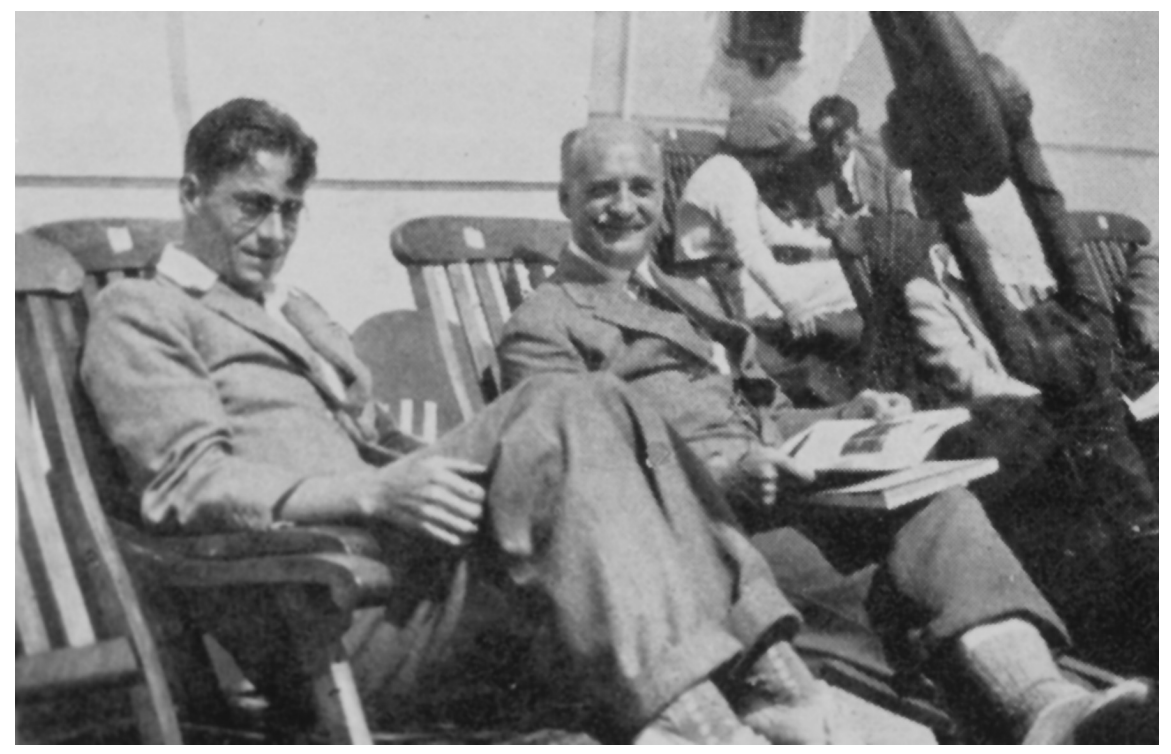

Fig. 2. Sitting on the right is Joseph Barcroft (August, 1929), en route to 13th International Congress of Physiologists in Boston on SS Minnekahda with Howard Florey (left). They published together twice around this period (Barcroft \& Florey, 1928, 1929). Participant physiologists from 22 countries spent 10 days on the boat; a 'pre-congress' (Franklin, 1953). Barcroft had previously tried to recruit Florey to Cambridge in 1926 (Macfarlane, 1979). the $20^{\text {th }}$ century M. Foster, J.N. Langley, ${ }^{2}$ Hopkins (Cambridge's first chair of Biochemistry, 1914-1943), Barcroft himself; and E.D. Adrian (neurophysiologist and Barcroft's successor as Chair of Physiology). He added the physicists J.J. Thompson and E. Rutherford.

Research relevant to the placenta took place in Physiology (Barcroft, F.H.A. Marshall, A.S. Parkes, R.S. Comline, Marian Silver \& Maureen Young), Anatomy (J.D. Boyd - our father, D.H. Steven), Biochemistry (J. Needham), Veterinary Science (J. Hammond), Experimental Medicine (R.A. McCance and Elsie Widdowson), and, very much a separate activity and stretching the definition of relevance over a longer time- frame, Physics (F.H.C. Crick \& J.M. Watson (Crick \& Watson 1953)) and Zoology (V.Rothschild).

We will focus especially here on Joseph Barcroft, the leading figure of the time (Franklin, 1953; Roughton, 1949; Weatherall, 2000), and, for reasons of personal knowledge, on J.D. Boyd.

\section{Joseph Barcroft}

In origin, Ulster-plantation Irish ${ }^{3}$, Barcroft (1872-1947) went both to Public School and to university in Cambridge. ${ }^{4}$ At Cambridge University he was a contemporary and friend of Ernest Rutherford (Roughton, 1949), and conducted, with the exception of two world wars, essentially all his research in its Physiology
Department. The physical bases of his life from adolescence: school, College, home and Department, all lie within Fig. 1, together with Cambridge railway station, to the east, his route into wider public roles.

Barcroft was a broad-ranging integrative and comparative physiologist. A talent well exemplified in 'Features in the architecture of Physiological Function' (Barcroft, 1934) which Krogh described as "a book which gives an integration of physiology of such a kind that it ought to be read by everyone who is going into experimental work in physiology" (Franklin, 1953); probably still good advice. He made deep contributions in sequence to at least four fields: salivary secretion and metabolism; the haemoglobin dissociation curve and the handling of blood gases extensively discussed in (Barcroft, $1925,1928)$; organ distribution of blood, especially the role of the spleen; and finally foetal physiology. Astonishingly, he only came to this final topic at age 60 but, before his death 14 years later, was able to summarise (Barcroft, 1946) a subject-changing corpus of work (vol 2 never appeared). This was, we suspect, achieved by the combination of a mind primed to follow lateral possibilities as they arose, as he had throughout his career, and a collaborative personal approach together with tremendous enthusiasm and the capacity to enthuse others.

Barcroft was a great collaborator (see e.g. Fig. 2). Near the start of his career he was invited by Zuntz, ${ }^{5}$ who had earlier co-authored the first detailed study of fetal blood gas metabolism, to participate

\footnotetext{
${ }^{2}$ Barcroft's predecessors as Chair of Physiology (1883-1903 and 1903-1925 respectively). According to F.G. Roughton (Roughton, 1949), Langley set Barcroft his first research project on salivary gland metabolism.

3 i.e. of Scots Protestant ancestry 'planted' by King James 1 on land of displaced native Irish in the 17th century.

${ }^{4}$ Public school is UK nomenclature for a fee-paying High School; in this case The Leys (Fig 1, bottom), a Methodist foundation, though Barcroft's family were Quakers. H.H. Dale was a fellow pupil. The Leys was later attended by A. Todd (nucleotide structure) and, much later, by Y.W. Loke (and by both of us). Barcroft acknowledges his Leys teacher, Dr. Kimmins, "who showed me the fascination of physiology" in his 'Respiratory Functions of the Blood' (Barcroft, 1931)

${ }^{5}$ Zuntz's technique (Cohnstein \& Zuntz, 1884) was subsequently developed by A.St.G.M. Huggett; used by Widdas; and extensively exploited by Barcroft - the publication demonstrates methodologically deeply impressive work.
} 


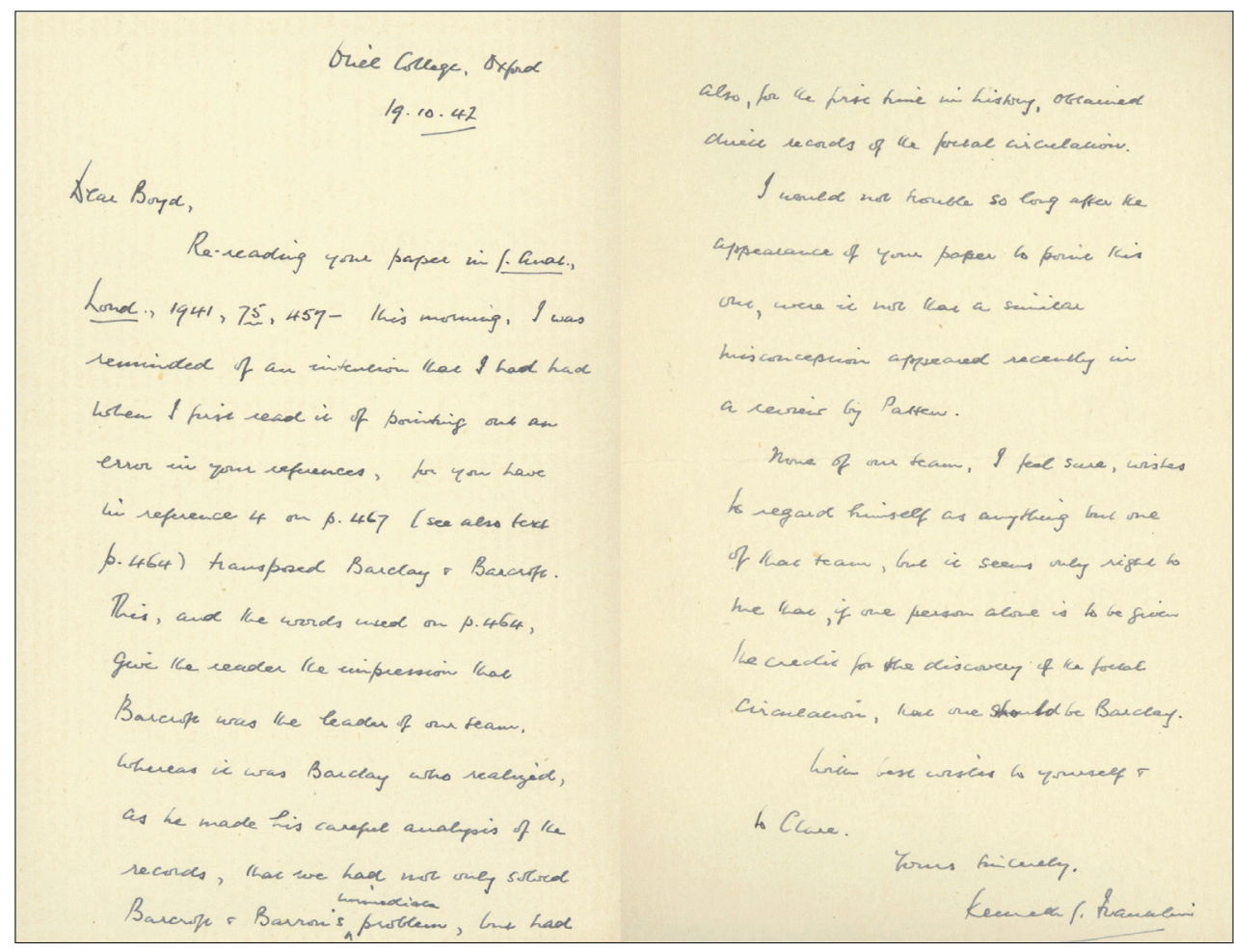

Fig. 3. Franklin's letter to Boyd. Then, as now, there could be sensitivities as to appropriate allocation of credit. Dated 19 October 1942.

in a study of blood gases at high altitude in Teneriffe. Subsequently, and before the start of his fetal physiology period, collaborators with whom he published included E.H. Starling, A.V. Hill, H. Florey, R. Margeria (G. Meschia's post-doc supervisor who later arranged a Toscanini Fellowship for him to work with Barron, Barcroft's associate, at Yale), H.A. Harris (Boyd's predecessor in Cambridge as Professor of Anatomy) and D. Keilin. Many attest to his capacity for hard work ${ }^{6}$ and also this ability to enthuse others. Memoirs, and family recollections, emphasise Barcroft's human talents in this regard: "Surrounded by a group of enthusiastic young people of great ability" (Krebs, 1967). Barron praises "his devotion to (the young) and a host of other intangible qualities. To emulate him was and will remain my life's purpose" (Franklin, 1953).

A collaboration led to Barcroft's first reproductive study (Lemberg et al., 1931) on Uteroverdin in the Uterus which followed logically from his interest in haemoglobin: "On Freudenberg's recommendation Lemberg had applied for a Rockefeller Foundation fellowship to go to Gowland Hopkins biochemistry department at Cambridge... Lemberg had been greatly impressed by the work of Keilin, Barcroft, and Robin Hill on haem compounds and cytochromes, and elected (1930-31) to continue his studies on the bile pigments rather than to participate directly in the work of the Hopkins school. This decision he later somewhat regretted.
However there was interchange of ideas particularly between the departments of physiology and biochemistry and the adjacent Molteno Institute, which Keilin directed. One day Keilin told him that Barcroft had a green pigment in the placenta of the dog. It turned out to be 'uteroverdin', which was identical with oocyan, the green pigment that Lemberg had isolated from gull's egg shells. .... Lemberg worked in the same laboratory as Robin Hill, who at that time was doing his brilliant pioneering work on photosynthesis" (Barrett \& Robinson, 1979).

Barcroft soon moved from molecular work into direct study of fetal physiology. Interestingly, and not widely noted, his collaborator on his first functional study on the live fetus (Barcroft et al., 1934) was none other than L.B. Flexner, to become one of the greatest mid-20 2 th century figures in placental physiology (Faber, 1999). Their paper refers to only three previous publications one being Zuntz \& Cohnstein (Cohnstein \& Zuntz, 1884). They also worked together on the Rabbit (Barcroft et al., 1934).

Much of Barcroft's fetal work was based on experiments using the pregnant ruminant. This preparation, used by Zuntz, had, as mentioned, been extensively developed by Huggett (1897-1968), who had had a brief collaboration with Barcroft on a different topic (Brambell, 1970) which is acknowledged in Huggett's resulting publication: "In conclusion, Ishould like to record my thanks to Mr. J. Barcroft for much advice, for facilities while at Cambridge, and for the loan of apparatus in London, enabling me to carry out this work. My thanks are also due to Professor Langley for permission to initiate this research in his laboratory." 7

As well as using the pregnant ruminant in Cambridge, Barcroft also collaborated with Franklin on the latter's studies of the fetal circulation, work initiated following a discussion between them "on the train to Oxford" - presumably the Bletchley line. This work (Barclay et al., 1944) on fetal circulation in Oxford (see Fig. 3), at its Nuffield Institute, preceded the arrival there, as director, of the pharmacologist G.W. Dawes who appears to have been drawn into fetal research because of Franklin's interest, although Dawes who, together with colleagues, spent the next 20 years further exploiting the acute ruminant model, filling in much detail, summarised in his influential 'Foetal and Neonatal Physiology' (Dawes, 1968) ${ }^{8}$, does not mention this likely indebtedness in his introduction.

Barcroft's closest associate in fetal research was undoubtedly

\footnotetext{
${ }^{6}$ Hodgkin (Hodgkin, 1992) recalls Barcroft telling him (in 1946 or 1947) that no, he didn't need the lights turned on to find his way to the basement door of the Department in the dark since "after thirty years he could find his way around the lab with his eyes shut".

7 Perhaps the most important scientist to emerge from Huggett's lab was W.F. Widdas who modelled some of Huggett's data on transplacental glucose transport and from this introduced the concept of 'the carrier' to biology (Boyd, 2005).

8 Barcroft's work is drawn on in 10 of its 17 chapters.
} 
Don Barron, to whom 'Researches on Prenatal Life' is dedicated. The admiration was reciprocated. "No one has contributed more generously to the physiological thought of this country (the USA) than Barcroft." (Barron quoted in (Franklin, 1953)). After Barron's return to Yale and appointment to its Chair of Physiology, the development with Meschia and colleagues (Meschia etal., 1965) ${ }^{9}$ of the chronic fetal preparation opened a new methodology extensively exploited by Meschia and Battaglia and their Denver colleagues to delineate fetal nutrition and metabolism and by fetal physiologists generally. According to Battaglia (Battaglia, pers. commun.), Barron, at the time when Meschia had just joined his Laboratory from Margeria's and when Battaglia was working with him on the thesis then required of medical students, "talked constantly of Barcroft and certainly felt, rightly or wrongly, that he was Barcroft's direct scientific descendant". It is also legitimate to wonder if Meschia's work with Barron on materno-fetal potential difference (Meschia, 1958), still a source of controversy, stemmed from a brief study in Barcroft's laboratory while he was there on trans-gastric potential (Quigley et al., 1937).

Barcroft was fascinated by the nutritional role of the placenta but he also, especially during World War II, applied his time and his thinking to a much broader canvas: the nutritional challenges of feeding national populations and indeed the world as a whole. Academically, he was founder Chair of the Nutrition Society. More practically, as Chair of the UK Government's Food Investigation Board, he was a leading supporter of dried food, a contributor to 1940s British nutrition. ${ }^{10}$ Such roles played into his belief in the need for a deeper understanding of the physiology and nutrition of farm animals. The Survey Group on Animal Nutrition of the Agricultural Research Council of which he was Chairman seems to have played a, perhaps the, key part in the decision to establish an Institute of Animal Physiology at Babraham near Cambridge $(\mathrm{H}$. Barcroft, 1975), currently the site of genetic studies of great relevance to the placenta (Constancia et al., 2005; Sibley et al., 2004).

\section{Some colleagues of Barcroft}

Hammond (1889-1964), a veterinary physiologist interested in whole animal growth in utero and beyond, and son, in his case, of a farmer, kept a practical foot in the farming world. He had been drawn into research by Marshall (Edwards \& Palladino, 2004). Though he never published with Barcroft, they knew each other's work well: "On a summer Saturday afternoon (Hammond) assembled outside the Physiology Department a Shire stallion which was travelling the district, a Shetland stallion, the Shire and Shetland mares that he had used and their foals. The contrast in weight and size was so enormous that it was difficult for the assembled scientists to believe the evidence of their eyes." (Slater \& Edwards, 1965) Hammond's son did publish with Boyd (Boyd etal., 1944). Joseph Needham's

\footnotetext{
9 A paper also notable for its acknowledgement of Leonardo da Vinci in its figure of uterine anatomy.

10 Dried egg is vividly remembered by those of us nourished at the time - fine nutrition, disgusting smell.
}

three-volume 'Chemical Embryology' (Needham, 1931; see also Gurdon and Rodbard, 2000 for a biographical memoir) is an underrated, comprehensive evaluation of the early biochemical literature; Boyd, in thanking Needham for the gift of a copy did however comment that 'Placenta' was not listed in the index. His later work on morphogenesis was singled out for praise in Boyd's 1943 summary of UK war-time embryological research (Boyd, 1943). Needham subsequently evolved academically via 'A History of Embryology' (Needham, 1934) to a (monumental) second career as the dominant expositor and scholar of Chinese Science in the West (Needham with others, 1955-2004); see also (Winchester, 2008). The painstaking contributions of McCance (18981993) \& Widdowson (1906-2000) on the 'Chemical composition of foods' (McCance \& Widdowson, 1991), originally started by McCance as a medical student in 1926 in collaboration with the early diabetologist R.D. Lawrence (preface to McCance \& Widdowson, 1991), and analyses of fetal composition by Widdowson allowing quantification of net placental transport, together with their work on the long-term impact of early nutrition (Widdowson and McCance, 1963), provided early experimental orientation for Barker's later (Barker, 1992) 'fetal origins' hypothesis. In 1938 McCance was invited to return to Cambridge as Reader in Medicine and in 1945 became there the first Professor of Experimental Medicine in Britain. As a young man McCance had, after consultation with his father, decided to make his career in agriculture in Northern Ireland and went to Cambridge where he took the Physiology course under Sir Joseph Barcroft, "who became one of his great heroes". This was followed by 3 years in the Biochemical Department under Sir Frederick Gowland Hopkins, where he obtained his PhD. A.S. Parkes (1900-1990), a key figure in reproductive endocrinology, returned to Cambridge towards the end of this period having, as a young scientist, supported F.H.A. Marshall (1878-1949) in finalising the second edition of his 'Physiology of Reproduction' (Marshall, 1922) before editing the

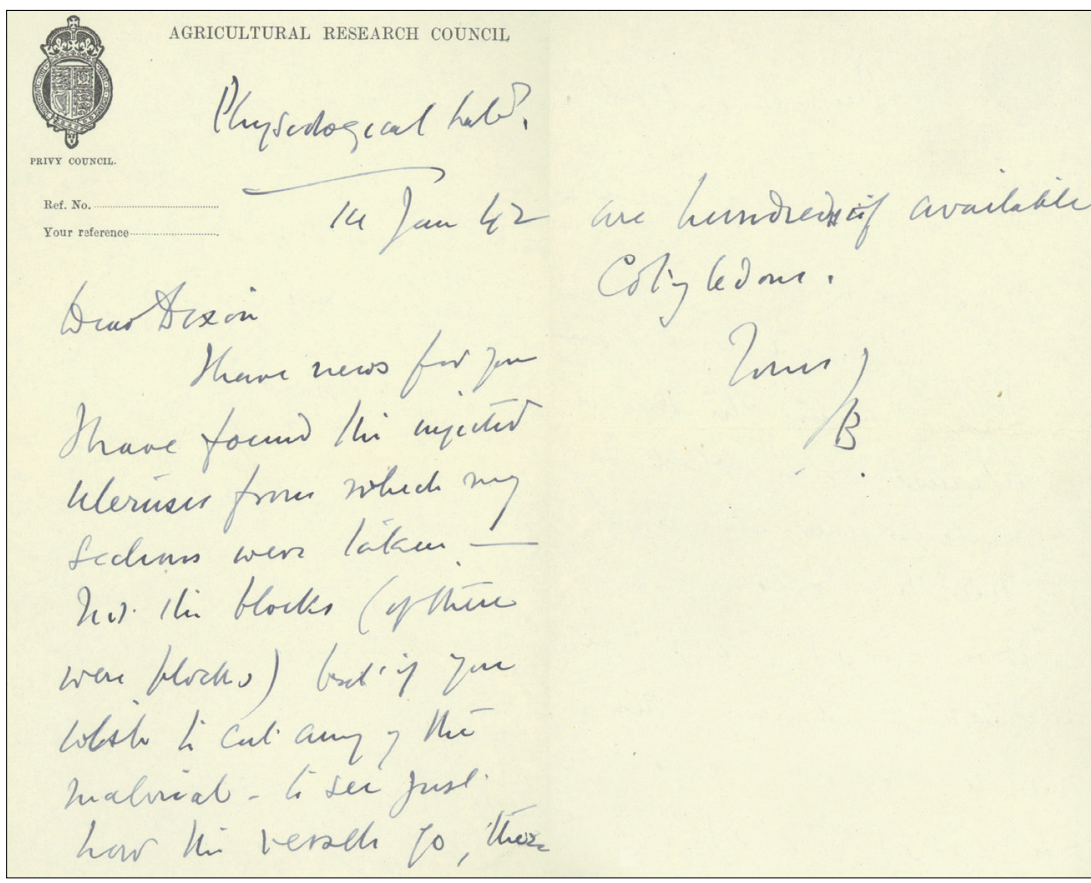

Fig. 4. Barcroft's letter to Boyd. Dated 14 January 1942. 


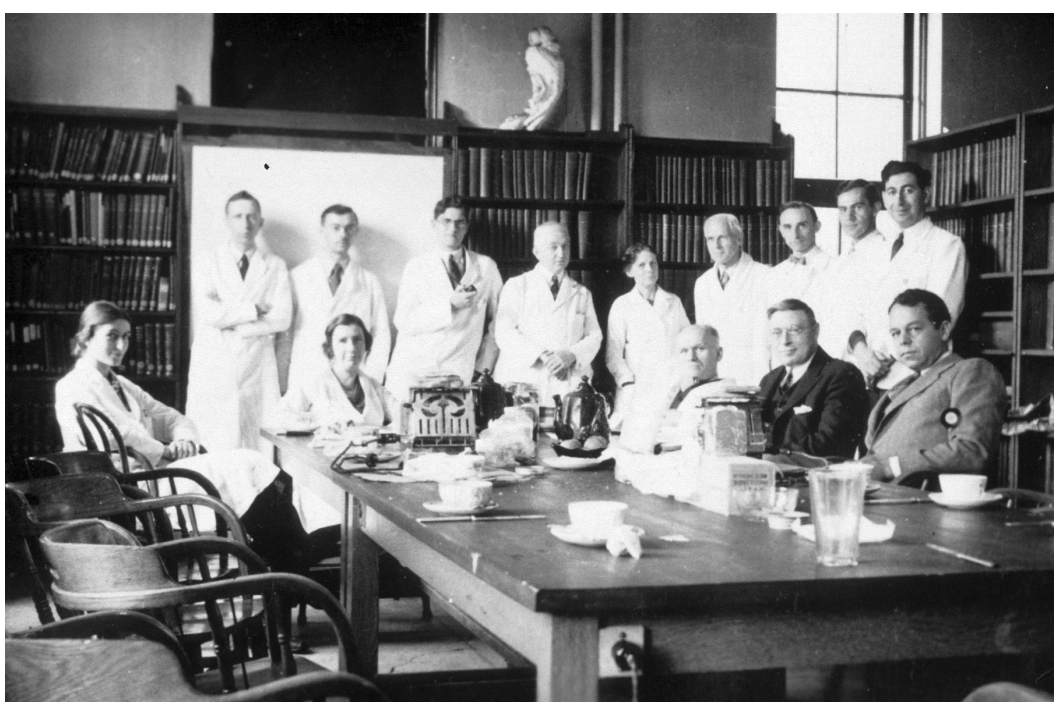

Fig. 5. Lunch in the Library. Streeter's group, Carnegie Institute (1934-35). Seated left: Amélie Boyd, née Loewenthal, Boyd's wife. Standing left to right: Mossman H.W., ? Rossi, Boyd. According to a note of A. Boyd's, Streeter G.L., co-dedicatee with Wislocki of the Princeton conference (Villee, 1960) and, with Bryce, of 'Human Embryology' (Hamilton et al., 1945) and Lewis are also in the picture. We cannot securely identify them or the others. (Authors' collection).

\section{third himself.}

J.D. Boyd (1907-1968). Dixon Boyd (Figs. 5,6) was an anatomist at a time when the spatial and structural domain was not considered to be an important perspective or the direction in which science was moving; Anatomy was unfashionable. His work was on neural and cardiovascular development, on malformation in embryogenesis and, latterly, on placental structure and development. Although they never published together, the Barcroft and Boyd families had close ties of friendship (one of us can half remember sitting on Barcroft's lap and playing with his fob watch as a small child). From very different seniorities, they engaged in scientific discussion. Barcroft makes reference to Boyd's help in the preface to 'Researches on Pre-natal Life' and raised queries with him in various short notes (see Fig. 4) which might ask a specific embryological question or even whether the publishers of 'Human Embryology' (Hamilton et al., 1945) would be suitable for 'Researches on Pre-natal Life' (they weren't chosen). Boyd's work on the carotid body (Boyd, 1937) is referenced in Barcroft's last published scientific paper (Barcroft \& Karvonen, 1948).

Boyd (though born in New York) was, like Barcroft and McCance, of Northern-Irish descent. A generation younger than Barcroft, he was recruited as a lecturer to Cambridge Anatomy in the mid 1930s after a fellowship in 1934-5, funded by the Rockerfeller Foundation, at the Carnegie Institute under G.L. Streeter (see Fig. 5), who greatly inspired him (Boyd, 1937).

In 1938, he was recruited to the Chair of Anatomy at the London Hospital Medical College but his department there was 'evacuated' to Cambridge and housed in the Geology Department, adjacent to Physiology (Fig. 1) for part of World War II. Following return to London, Boyd's home was destroyed by a 'flying bomb' and he lived for a while nearby with Barcroft's fellow physiologist, A.V. Hill. He returned permanently to Cambridge in 1951 as Chair of Anatomy (to live initially in E.D. Adrian's house (Fig. 1)) and remained in that role until shortly before his death in 1968.

Boyd had met W.J. Hamilton, yet another Ulsterman and his lifelong collaborator at medical school in Belfast (Ireland) together with both their wives. Walmsley, its Professor of Anatomy was the inspiration of several future Chairs. Mossman, at the Carnegie Institute of Embryology at the same time as Boyd (Fig. 5) (Mossman, 1991) was also inspired by Streeter and collaborated with Boyd and Hamilton on 'Human Embryology' (Hamilton et al., 1945). However its preface indicates that the war had "made collaboration between (them) much less intimate than had been planned". Boyd and Hamilton worked intermittently together on human placental structure for over 30 years. Possibly Hamilton's 1943 paper (Hamilton et al., 1943) triggered the initial interest following the precedent of Streeter (Streeter, 1926) and subsequently Hertig and Rock (Hertig \& Rock, 1941). As the essential basis for their work, Boyd and Hamilton collected human embryological and placental material over many years "through the collaboration, often at great personal inconvenience, of obstetricians, gynaecologists, pathologists and general practitioners" who are acknowledged in 'The Human Placenta' (Boyd \& Hamilton, 1970), their joint monograph, which Hamilton saw through the press following Boyd's death. The collection and preparation of the material depended heavily in our memory on two technicians, J.F. Crane and K. Thurley in Cambridge though others are also mentioned in the volume. E.J. Park worked with Hamilton at Charing Cross Hospital Medical School in London on material there.

\section{Sociology and ethos of mid $20^{\text {th }}$ century Cambridge Bioscience: a view from childhood}

Despite obvious continuities, biological science in Cambridge half a century ago was conducted on a local and wider context different, sometimes subtly different, from today. ${ }^{11}$ Boyd's view appeared to be that science was vocation, profession and hobby combined. This seems to us to have been generally true of his colleagues. His philosophy could be exemplified by noting that, in talking to us as children, one of his commonest phrases was that this or that scientific understanding was "a beautiful story".

For Barcroft, an important talent, obvious in all his books - not least in 'Researches on Prenatal Life' - is the application of simple 'back of the envelope' calculation in giving relevance to the significance of an observation in the context of overall physiological function. ${ }^{12}$

Boyd describes Barcroft as "concerned always with first principles and taking details in his stride. I shall always remember how he could put one back on the tracks again by pointing out how

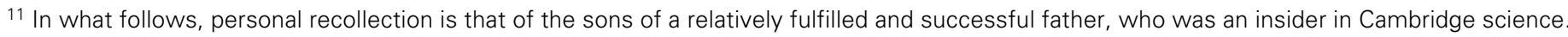
It may well not reflect the views of others differently placed in the then hierarchy.

12 Fermi \& Einstein both have the phrase attributed to them; colleagues, of course, of Rutherford, Barcroft's student friend.
} 


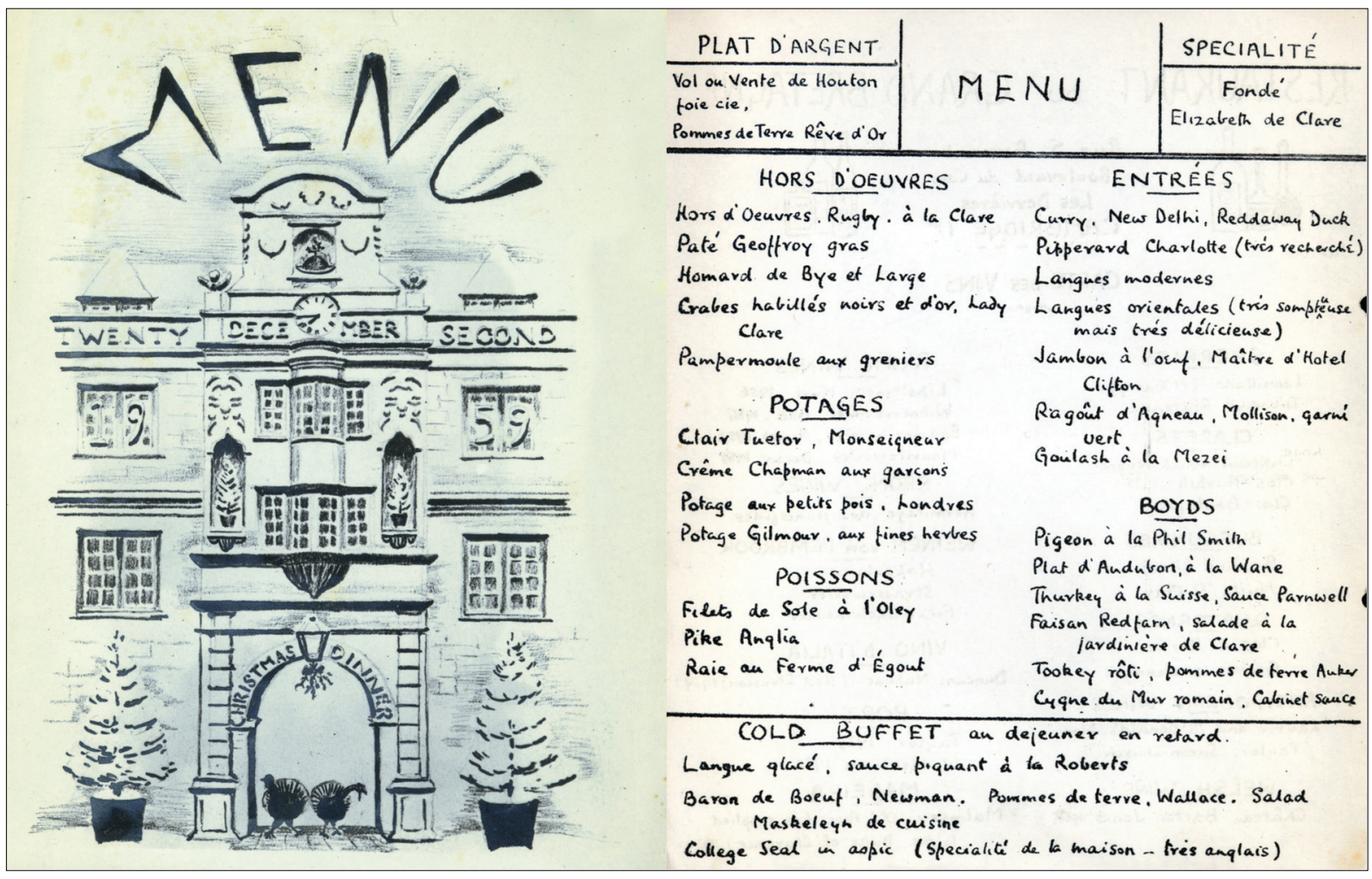

Fig. 6. Menu at Clare Christmas Feast (22/12/1959). This menu was drawn and the punning on Fellows' names was created by E.N. Wilmer, a distinguished histologist.

one's apparently bright thought transgressed one or other of the primary laws." (Quoted in (Franklin, 1953), p 342). This placing of experimental findings in the context of general principles, or of quantitative thinking, also seems to us to have been a widespread feature of thinking amongst this group of individuals and their Cambridge scientific contemporaries. ${ }^{13}$

Several aspects of society at the time contributed to what we perceive as a tendency to 'think big' which we believe senior academics at that time and place felt was to be their duty.

\section{Gender, social networks and class}

At this time nearly every scientist was a middle-class male supported by a domestic wife and, certainly at the professorial level, by servants - perhaps part-time in the house after children had started school, and in the garden. The few women in science (e.g. Widdowson, Young) were often childless. Our mother was a physician and published (junior) researcher, as were Hamilton's wife and Barcroft's daughter-in-law. None of them (except during World War II) did more than very part-time medical work, e.g. in health promotion clinics for babies or school children. The paramount importance of support for the husband's science was taken for granted. Boyd certainly worked every day including holidays excluding only Sunday mornings when he stayed in bed until lunchtime - but he may well not have seen it as work.
Social relations were intimately intertwined with the scientific. In the Downing Street site, home within a few moments walk of each other, to the Departments of Anatomy, Physiology, Pathology, Biochemistry, the Molteno Institute and close by Zoology (Fig 1 ), there would be numerous casual encounters on the tarmac, over the bicycle or on the stairs (no lifts). There was little or no car commuting. As was true of most of their friends, the Boyds had no car in the 1940s.

The Colleges were predominantly a social and residential base for students and their non-laboratory teaching. However, membership of one carried the obligation (see Fig. 6) of 'dining in' which provided a convenient opportunity for male colleagues to meet in a family-free environment and to entertain those from out of Cambridge. The fellowship (i.e. faculty) of individual colleges being small in number and widely diverse in discipline, ranging, perhaps, from theology to physics, was at first sight not an obvious locus for scientific discussion. In reality, our impression is that the resultant cross-ranging conversations may have contributed importantly to the philosophically broad-focus attitude to experimental findings held by Barcroft, Boyd and many of their contemporaries

In the domestic setting wives and junior colleagues were included; indeed wives made the running. For larger groups there were 'Sherry Parties'. More frequent were rather formal dinners (adults and grown-up children) or, more informally, 'Sunday

\footnotetext{
13 One of us can recall a 1955 Sunday lunchtime conversation in R.D. Keynes' house between him and R.H. Adrian (his brother-in-law) concerning what limited the ability of the, then new, nuclear submarines to stay submerged; this involved an estimate of the quantitative balance between pulmonary and lower gastro-intestinal gas exchange and production respectively. The entry assumptions for this calculation were several!
} 
lunch'. Generally the wife shopped and cooked, the vegetables being perhaps washed and sliced by the 'daily'. The children helped with the washing-up and would osmose a certain attitude to science and perhaps to the academic politics of who was esteemed and, especially, who was not!

Technical staff were not seen as 'officer material', being always addressed by surname while referring to our father as "Professor". Of course, they were central to the success of the academic endeavour and could sometimes become renowned or cross the barrier to an academic position (e.g. Hopkins - though his route through private labs and doing analyses of poisons for the courts was unusual (Hopkins, 1949; Weatherall, 2000)). This impression that entry to science was narrowly class-dominated is nevertheless a misconception. Boyd's single-parent father kept a village corner shop cum post office. This was not untypical; the Fellowship of his college, Clare, when he joined it in the 1930s was, according to Boyd, almost exclusively composed of ex-grammar school boys like himself, rather than of the alumni of the feedemanding public schools. It was rather that, in the work context, an individual was, in the hierarchical concepts of the time, either 'officer' or 'other ranks'.

\section{Teaching}

Teaching at a junior level was a clearly understood role of the senior academic. According to Roughton (Roughton, 1949), Barcroft, when he became head of department, "took over a large section of the first year lectures in physiology". Similarly Boyd, as head of Anatomy, gave the students all their embryology lectures and also taught topographic anatomy and neuroanatomy. One of us, a medical student in Cambridge in the 1950s, remembers that this was in no way unusual: the departmental chairs of Pharmacology, Physiology (after Barcroft's time) and Pathology all similarly contributed junior lecture courses or demonstrations, perhaps of a classical animal experiment, and these were generally of high quality; many of the issues raised in them have stayed in his mind throughout his career The ability of researchers such as Barcroft to move laterally and seamlessly into fruitful new areas as their research careers evolved may have owed something to the breadth required by teaching duties. But there could be another view. A. Bellairs relocated with Boyd to Cambridge in 1951 accompanied by another recruit to the Cambridge department, his wife Ruth. Both left within a year, partly because of the heavy teaching demands (Gans \& Crews, 1991).

\section{Funding for research}

Apart from various (junior) Research Fellowships - such as the Beit (for Huggett) and Rockefeller (for Lemberg or Boyd) - funding in general went with the Department, giving the Professor substantial flexibility. ${ }^{14}$ To the best of our knowledge, our father never wrote a formal research grant though he certainly wrote the odd letter seeking special funds. Barcroft had major Rockefeller funding; and we are aware of significant support during his Haemoglobin phase from the Medical Research Council's (MRC's) 'Haemoglobin Committee' (preface Barcroft, 1928) and from the

\footnotetext{
14 Two generations before, Professors had paid juniors out of their own personal emolument (Fozzard, 1983).
}

ARC (Agricultural Research Committee) in his fetal research. Our impression is that external funding was dependent on standing and word of mouth rather than on formal peer review. This impression is supported by Weatherall's report that W.M. Fletcher (the Secretary of the UK Medical Research Council from its establishment after World War I until 1933) who had "fought tooth and nail to retain its independence" and Pearce (the Rockefeller administrator) discussed and decided not to support a Medicine Chair relocation to Cambridge (of T.R. Lewis) (Weatherall, 2000). More substantially, "the Dunn and Rockefeller bequests to $\mathrm{Pa}$ thology and Biochemistry at Oxford and Cambridge ... were coordinated by Fletcher". Fletcher had been a contemporary of Barcroft in the Physiology Department in earlier years, and a political ally in curricular discussions there. Funding bodies' responsiveness to requests from scientists of standing allowed further flexibility in responding to research and related human opportunities. For example, McCance was easily able to access support to allow a dietician, Widdowson, to join him through "a grant for her from the Medical Research Council-it was much easier to do this then than it is now-" (Ashwell, 2002). In the establishment of larger groups or of new sub-departments the attitude of the relevant subcommittee of the University Grants Committee or of the Scientific Secretary of a Research Council was dominant. For Hammond, interestingly (Edwards \& Palladino, 2004) funding was always tight. Was this because he did not have an established major disciplinary department? Within Departments, science was not managed beyond recruiting individuals with talent supported, perhaps, by an influential patron such as Sherrington's support for Florey mentioned below (Macfarlane, 1979), with their teaching role at the forefront. Such individuals might or might not fit well with the research area of a well-known senior or Head of Department. The majority of those we mention above were talent-spotted as students; (Hammond, Barcroft, Needham) or appointed as lecturers to fill a teaching niche (Boyd). Departmental Professors were appointed by 'Electoral Boards' which were in place, we believe, regardless of whether there was an existing or upcoming vacancy. Occasional appointment at a senior level might be to a targeted niche (such as Hopkins, (Weatherall \& Kamminga, 1992)).

There was little direction or control of juniors or effort to synchronise or manage their research activities. For example, A.L. Hodgkin (Hodgkin, 1992) describes asking Barcroft in 1937 if Barcroft, as head of Department, needed to give permission for Hodgkin to submit his first paper to a journal: Barcroft was quite taken aback and explained to the young scientist "first that we did not do anything like that in Cambridge; and second that anything I wrote was entirely my own affair". Within Boyd's Department there were a wide variety of research interests including: comparative morphology (C.C.D. Shute); histochemistry (P.R. Lewis); developmental biology (B. Towers); chromosomes (E.H.R. Ford); carotid body/chromaffin cells (J.D. Lever); electron microscopy (A.F.W. Hughes - Crick's supervisor); dental development in tissue culture (S.G. Hughes); circulation of cerebrospinal fluid (J.W. Millen); development of the cranium and hydrocephalus (D.H.M. Woollam); neurobiology of learning (G. Horn); and embryology, later applied in the context of global population control, (D.M. (Malcolm) Potts). More senior staff were certainly not managed. From memory, our father's contract of employment as Professor of Anatomy merely stipulated that he live within 10 


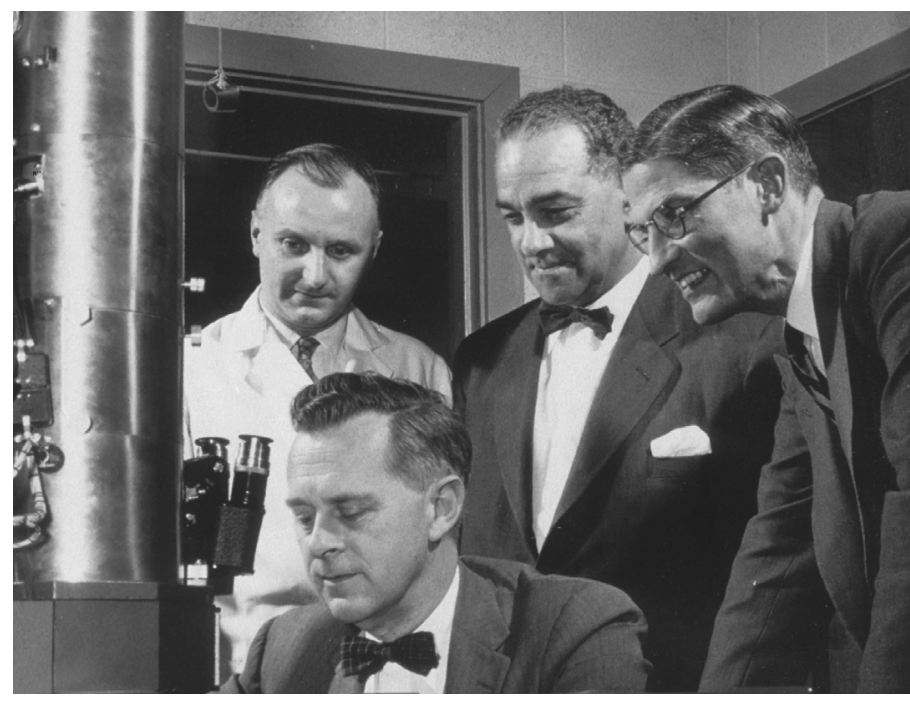

Fig. 7. J. Dixon Boyd with an early Electron Microscope, Nov., 1958, at the time of a conference in Princeton NJ sponsored by the Association for the Aid of Crippled Children (Villee, 1960). Location uncertain, probably St Louis in Dempsey's Laboratory. Left to right standing: Davies J., Amoroso E.C. and Boyd; seated: Dempsey E.W. (Authors' collection). Boyd and Hughes published one of the first two studies of placental ultrastructure (Boyd \& Hughes, 1954).

miles of Great St Mary's (the University Church in Cambridge) during Full term (eight weeks three times a year).

\section{International context}

The international context may also have contributed subtly to a 'think big' ethos. Individuals took the historical consequences of The British Empire for granted. Careers of British academics in this period often included periods in Colonial or Commonwealth Universities and recruitment from them, e.g. in Anatomy of T.A.I. Grillo, P.H. Sebuwufu and V. Navaratnam, was commonplace. ${ }^{15}$ Boyd did not configure himself as other than British despite an Irish childhood. Neither Barcroft nor he had appointments in the "Empire" though Boyd "examined" medical students or inspected facilities in the Sudan and in Nigeria. Anrep, briefly in Barcroft's Department, later worked in Egypt where M. Panigel, the placental physiologist, was his student and admirer (Panigel, personal communication, about 1985). Henry Barcroft described a scurrilous rumour that, while in Cambridge, "Anrep was thought to have murdered his wife, so he was found a chair in Cairo" (Barcroft H, personal communication, about 1985). The account of Anrep's domestic life in his Royal Society obituary is not totally incompatible with the rumour (Gaddum, 1956). True or false, the rumour is evidence of a belief, probably well founded, that a University, such as Cambridge, could heavily influence an individual's career placement across countries marked pink, the British colour, on the map and even into countries such as Egypt, only informally in the British sphere of influence. It also illustrates a contemporaneous attitude to such countries. ${ }^{16}$

Funding opportunities could be Empire-related. The Molteno Institute, adjacent to the Anatomy Department which Keilin, Barcroft's co-author on the Uteroverdin paper, directed, had been endowed by Molteno in 1921 for the study of parasitology, "indispensable if Africa is to be made habitable for white men" (Weatherall, 2000, page 164).

The USA connection was deep and wide. Barcroft made several trips. He gave the Edward K. Dunham lectures at Harvard in 1929 (Barcroft, 1929); the basis for 'Features in the Architecture of physiological Function'. A visit in 1933 to Cornell, Toronto and Chicago included a talk acknowledging his debt to, amongst others, Huggett. In 1936 he spoke at the Harvard tercentenary celebrations. During each of these visits he spent time with a positive roll call of distinguished bioscientists from Gesell to Best and Van Slyke to Peyton Rous (Franklin, 1953); wide ranging interests indeed.

Boyd spent 1934-5 in Baltimore (Boyd, 1937), being recruited to Cambridge Anatomy as a lecturer on his return. In the 1950s he visited the US several times to attend Macy (Dancis, 1994) or other conferences (Fig. 7). US colleagues who worked in his departments included Ed Dempsey (Fig. 7), Thomas Lewis and Florence Moog.

Refugees from Germany were also a major feature of Cambridge academic life from 1933 onwards. A.V. Hill and Barcroft's colleague as a Kings College Fellow, Maynard Keynes, were heavily involved in attempting to assist their entry into and employment in the UK through establishing a Society for the Protection of Science and Learning (Medawar and Pyke 2000). Boyd was a member of its committee. ${ }^{17}$ While such luminaries as Krebs came to Cambridge at this time and for this reason, none was particularly involved with feto-placental research.

\section{The Clinical interface}

While many bioscientists (not Barcroft) were clinically qualified

\footnotetext{
15 In Barcroft's generation, Rutherford was a striking example.

16 Before Anrep's Cambridge appointment the post had, by Barcroft, first been offered to H.W. Florey, an Australian by origin, who was "flattered to death, as it is about the best in England". The letter informing him of a (generous) salary had gone astray while Florey was working in Philadelphia with the renal physiologist A.N. Richards on a Rockefeller fellowship and he had declined, before he received the letter, in the mistaken belief that he could not afford to take the post, (Macfarlane, 1979; Macfarlane \& Abraham, 2004). Florey, at that time a physiologist, had published with Barcroft (Barcroft \& Florey, 1928; 1929) during an earlier appointment in the Cambridge Pathology department where he had been recruited, at C.S Sherrington's suggestion, to bring physiology to the discipline. Florey, like Barcroft, had "the ability to reduce a problem to simple questions answerable by experiment" (Macfarlane \& Abraham, 2004). It is tempting to wonder how fetal and placental study might have evolved had he joined Barcroft. In the event, he moved further into general pathology and thence eventually to penicillin (again funded by the Rockefeller Foundation). When appointed to his first Pathology Chair in Sheffield it was complained that his appointment was unfair to other young pathologists who had trained properly in the subject (Macfarlane \& Abraham, 2004)!

17 Sadly the Society's work continues to be necessary and it continues such work under its revised name of the Council for Assisting Refugee Academics (CARA).
} 
in human or, occasionally, veterinary medicine, direct links with research clinicians were limited.

A major role of the 'Preclinical Departments' was the teaching of medical students. But this was only for three years before they proceeded to their Teaching Hospital, usually in London as, paradoxically, at that time there was essentially no clinical teaching in Cambridge (Weatherall, 2000). This could make academicclinical collaboration problematic. Nevertheless, Barcroft, in presenting his research, frequently emphasised its human applicability. Even in his seventies he made studies on new-born babies at the research-oriented Hammersmith Hospital in London and showed a film made at the West-Middlesex Hospital on intrauterine fetal movement; both achieved in collaboration with supportive clinicians, academic and non-academic. He was an important figure in a longstanding curricular debate in Cambridge, wishing to support a scientific, rather than a vocational, approach to medical student education (Weatherall, 2000).

Boyd, and Hamilton, were medical. Those who collected the material they used (Boyd \& Hamilton, 1970, preface) were, as with Barcroft's clinical collaborators, not necessarily otherwise research-oriented. There were no legislative controls at the time on such collecting and we doubt if the women concerned were ever asked for consent. ${ }^{18}$

\section{Revisiting Science 50 years later}

Clearly from some perspectives there has been great improvement. Nepotism is diminished; colonial stereotypes have reduced; and women have an opportunity to contribute on something like equal terms (though the disappearance of role differentiation - caricatured by the back-up wife supporting the male with his time fully at the disposal of his science - by typically two adults fully occupied by multiple tasks has left less time to the scientist of either gender for discourse with colleagues, for reflection and for wide reading).

Science is conducted on a much wider geographical scale both nationally and internationally. Funding has greatly increased. And methodologies have developed allowing old questions to be approached in an entirely new way and indeed allowing completely new questions to be asked.

In the light of these improvements has progress been proportionate to the increased opportunity? The burden of accountability and monitoring appears to have increased with little fully inclusive cost-benefit analysis. In the scientific domain the perception we have is that, in Cambridge at its best, in the period we have considered, the main accountability, once appointed, was a moral pressure to have the respect of one's peers (current and de- ceased) in working and thinking about adding a significant quantum to overall understanding and to do this to a high standard and to avoid becoming 'derivative'. ${ }^{19}$

This accountability has been replaced by perhaps blunter process tools, such as degree of grant funding, and of commercial funding, and explicit monitoring of 'productivity'. The inevitable pressure these lead to for 'quick' results to succeed in a short-term funding cycle can lead to over-publishing and more generally supports an ethos where the benefits of early exploitation are in the long run diminished or lost because of a rise in practices which leave unfashionable/unidentified big questions unaddressed. Could an individual of 60 today launch into a field new to them, as Barcroft did (Young, 1992), and transform it? Arguably the split between teaching and research - as they have each tended to become separately professionalised - will have also made this more difficult. The loss of the scholarly monograph exemplifies this split.

\section{Some placental legacies of mid-20 ${ }^{\text {th }}$ century Cambridge}

Those who worked with Barcroft, most notably Barron and through him Meschia and Battaglia, developed fields of study which continue today. The Babraham Institute, effectively Barcroft's legacy, has become an international site of leadership in reproductive genetics through $A$. Surani and his pupil W. Reik. In Physiology, under his successors, the department's key reputation moved to neuroscience but placental work by R.S. Comline and his colleagues, mainly ruminant, continued. After Boyd's early death D.H. Steven, who joined Anatomy in a new veterinary subdepartment towards the end of our period, continued active placental research (Steven, 1975) in Anatomy, mostly comparative. The human material which Boyd collected was fortunately not discarded and has recently been widely and profitably exploited with new techniques and new questions under G. Burton's leadership (Google cites 166 references to the collection at the present time). It is currently a source of particular satisfaction to us that a major new Centre for Trophoblast Research, intimately connected with the work of Y.W. Loke, was opened in Cambridge in 2007. In it, the groups led by Abbie Fowden, who had worked with Comline, and by Graham Burton which have strong and productive links with Babraham, (and also with Colin Sibley in Manchester (Fowden et al., 2006; Sibley et al., 2004) who has a one-remove connection with earlier Cambridge through a longterm collaboration with one of us) will come together with those who build on his immunological studies in Cambridge Pathology. Barcroft and Boyd would, one hopes, have been pleased to note this new initiative linked across the generations to work they so

\footnotetext{
${ }^{18}$ Control in this and other areas is now the subject in the UK and other jurisdictions of onerous legislation and monitoring. Then, such controls were light or non-existent. Investigators collected entire uteri with fetuses in situ without a by your leave. We were at liberty to walk up to the animal house on the top floor of Anatomy and show the animals to our friends and remember absolutely no sort of security to prevent anyone doing so. Safety was not an obsession either; on a morning off school one of us might be allowed to play unsupervised, screening our hands on the London Hospital Anatomy Department's 'teaching' X-ray apparatus. At the same hospital we might be sent to play quietly in the pathology museum admiring siamese twins in bottles or 'the Elephant Man' in a glass case whose continued exhibition was considered inappropriate once a popular movie of that name on the life of the individual concerned - who had in life been cared for by a London Hospital surgeon - was released!

${ }^{19}$ Appointment to a Departmental Chair meant in effect that a research grant at a medium level had been given to that individual until retirement, peer reviewing being confined to the appointment process. This allowed a long-view approach to big questions, now conspicuously curtailed by three- and five-year funding time frames. It also allowed the approach to the future by the selected candidate to be of his own choosing and with a flexibility of direction and timing he could choose.
} 
enjoyed and which, in turn, was built on their predecessors. This resurgent interest in the placenta fits nicely with Boyd's prediction (Boyd, 1959) that "surely the placenta will deserve increasing attention for it is the essential structural basis of the prenatal relationship between mother and child. ...For any satisfying explanation of the relation of the unborn child to its mother the darkness of the intrauterine workmanship must first be made visible and the inscrutability replaced by biological answers to rational questions".

\section{Allen Enders and the placenta}

Allen has over the years met, and continues to meet, two requirements which must underpin any comprehensive, 'big question' approach by the scientific community to understanding the placenta. First, for an individual to know and understand structure intimately and to share this understanding with others. Second, for a researcher to understand and exploit and help others exploit its amazingly diverse structure across species. We have not identified any direct organic link between Allen's great and lifelong contribution to meeting these two requirements and Barcroft's Cambridge, two generations ago and the other side of the world, though he did, early in his career, collaborate with R.J. Harrison, Boyd's successor in Anatomy (Enders, 1963).

We have neither of us had the pleasure of working directly with Allen but we note a, to us pleasing, cross-generational link in his acknowledgement of use of the 'Boyd collection' in an interesting recent paper with Anthony Carter (Carter \& Enders, 2004).

Working with Allen clearly is a great pleasure. Carolyn Jones who has, several times, most recently on the Hyena (Jones, 2006), describes him as "just amazing ... such a willing collaborator and a fount of knowledge always interested in every aspect of science; nobody too small for him to notice" (personal comment, 2008). All this resonates with Barcroft's style. There is also his personal intergenerational experience in biology, noted at the head of this chapter, which is reminiscent, as we have indicated, of several Cambridge families in the same broad field and generation.

\section{Acknowledgment}

We are grateful for helpful comment on an early draft by Professor John Pickstone.

\section{References}

ASHWELL, M. (2002) E.M. Widdowson Biographical Memoirs of Fellows of the Royal Society 48: 483-506

BARCLAY, A.E., FRANKLIN, K.J. and PRITCHARD, M.M.L. (1944). The Foetal Circulation and Cardiovascular System and the Changes that they undergo at Birth. Oxford Blackwell Scientific.

BARCROFT, H. (1975). I. de Burgh Daly. Biog Mem Fellows of the Royal Society 21: $196-226$.

BARCROFT, J. (1934). Features in the architecture of Physiological Function. Cambridge University Press Cambridge.

BARCROFT, J. (1928). The Respiratory Functions of the Blood: Part 1 Lessons From High Altitudes CUP 1925; Part 2 Haemoglobin CUP.

BARCROFT, J. (1931). Respiratory Functions of the Blood. Vol 1. Cambridge University Press.

BARCROFT, J. and BARCROFT, H. (1923). Observations on the taking up of Carbon Monoxide by the Haemoglobin in the spleen. J Physiol. 58: 138-144.
BARCROFT, J. and KARVONEN, M.J. (1948). The action of carbon dioxide and cyanide on foetal respiratory movements: the development of chemoreflex function in sheep. J Physiol. 107: 153-161.

BARCROFT, J., FLEXNER, L.B., HERKEL, W., McCARTHY, E.F. and McCLURKIN, T. (1934). The utilisation of oxygen by the uterus in the rabbit. JPhysiol. 83:215221.

BARCROFT. J. and FLOREY, H.W. (1928). Some factors involved in the concentration of blood by the spleen. J. Physio/66: 231-344.

BARCROFT, J. and FLOREY, H.W. (1929). The effects of exercise on the vascular conditions in the spleen and the colon. J Physio/68: 181-189.

BARCROFT, J., FLEXNER, L.B. and MCCLURKIN, T. (1934). The output of the fetal heart in the Goat. J Physio/82: 498-508.

BARCROFT, J. (1946). Researches on Prenatal Life. Vol 1. Blackwell, Oxford, UK

BARCROFT, J. (1929) Dunham Lecture. Harvard University Press, Cambridge Mass.

BARKER, D.J.P. (1992). The Fetal and Infant Origins of Adult Disease. BMJ books

BARRETT, J. and ROBINSON, R. (1979). 'Max Rudolf Lemberg 1896-1975'. Records of the Australian Academy of Science 4:133-156.

BOYD, C. (2005). How membrane carriers function: the critical contribution of W.F Widdas (1952) to modern understanding. Cell Mol. Biol. 51: 621-623.

BOYD, J.D. (1959). Some Aspects of the Relationship between mother and child: The Campbell Oration. Ulster Med. J. 28: 35-46.

BOYD, J.D. and HAMILTON, W.J. (1970). The Human PlacentaHeffer, Cambridge, UK.

BOYD, J.D. and HUGHES, A.F.W. (1954). Observations on human chorionic villi using the electron microscope. J Anat Lond88: 356-362.

BOYD, J.D. (1943). Embryology in War-Time Britain. Anat.Rec. 87: 91-97

BOYD, J.D. (1937). The development of the human carotid body Contrib Embryol. Carnegie Inst Wash 26: 1-31.

BOYD, J.D., HAMILTON, W.J. and HAMMOND, J. Jr. (1944). Trans uterine ("internal") migration of the ovum in sheep and other mammals. J Anat78: 785 814.

BOYD, J.D., HAMILTON, W.D. and BOYD, C. (1968). The surface of the syncytium of the human chorionic villus. J Anat 102: 553-563.

BRAMBELL, F.W.R. (1970). A.StG. Huggett 1897-1968. Biographical Memoirs of Fellows of the Royal Society 16: 343-384

CARTER, A.M. and ENDERS, A.C. (2004). Comparative aspects of trophoblast development and placentation. Reprod Biol Endocrino/2: 46-54.

COHNSTEIN, J. and ZUNTZ, N. (1884). Untersuchungen über das Blut, den Kreislauf und die Athmung beim Säugethier-fötus. Pflugers Arch 34: 173-233.

CONSTÂNCIA, M., ANGIOLINI, E., SANDOVICI, I., SMITH, P., SMITH, R., KELSEY G., DEAN, W., FERGUSON-SMITH, A., SIBLEY, C.P., REIK, W. and FOWDEN A. (2005). Adaptation of nutrient supply to fetal demand in the mouse involves interaction between the lgf2 gene and placental transporter systems. Proc Nat/ Acad Sci USA 102: 19219-19224.

CRICK, F.H.C. and WATSON, J.D. (1953). Molecular structure of nucleic acids; a structure for deoxyribose nucleic acid. Nature 171: 737-738.

DANCIS, J. (1994). Classics revisited: The Josiah Macy, Jr Conferences on Gestation. Placenta 15: 339-340.

DAWES, G.S . (1968). Foetal and Neonatal Physiology, Year Book Medica Publishing Chicago.

EDWARDS, J. and PALLADINO, P. (2004).Sir John Hammond (1889-1964); physiologist and agricultural scientist. Dictionary National Biography Oxford University Press.

ENDERS, A.C. (1963). (Editor.) Delayed Implantation Chicago, Rice University, USA

ENDERS, A.C., ENDERS, R.K. and SCHLAFKE, S. (1963). An Electron Microscope Study Of The Gland Cells Of The Mink Endometrium. J Cel/ Bio/18: 405.

ENDERS, R.K. (1956). Delayed Implantation in mammals, Transactions of the second Josiah Macy Conference ed Villee C.A. Josiah Macy Jr Foundation New York 113-131.

FABER, J.J. (1999). Classics Revisited: Flexner's $\mathrm{Na}^{+}$Clearances and the histological structure and age of the placenta in various species. Placenta 20: 141- 
147.

FOWDEN, A.L., SIBLEY, C., REIK, W. and CONSTÂNCIA, M. (2006). Imprinted genes, placental development and fetal growth. Horm Res. 65 Supp/3:50-58.

FOZZARD, J.A. (1983). Professors of Anatomy in the University of Cambridge privately printed.

FRANKLIN, K.J. (1953). Joseph Barcroft, Blackwell Oxford.

GADDUM, J.H. (1956). Gleb Anrep1891-1955. Biographical Memoirs of Fellows of the Royal Society 2: 19-34.

GANS, C. and CREWS, D. (1992). Biology of the Reptilia Vol 18 (E) (Physiology, Hormones, Brain and Behaviour). University of Chicago Press, London.

GRAY, A. (1926). Cambridge University: An Episodical History, Heffer Cambridge.

GURDON, J.B. and RODBARD, B. (2000). Biographical memoir on Joseph Needham (1900-1995). Int. J. Dev. Biol. 44: 9-13.

HAMILTON, W.J., BARNES, J. and DODDS, G.H. (1943). Phases of maturation, fertilization and early development in man. JObstetrics and Gynaecology of the British Empire 50: 241-245.

HAMILTON, W.J., BOYD, J.D. and MOSSMAN, H.W. (1945). Human Embryology Heffer Cambridge.

HERTIG, A.T. and ROCK, J. (1941). Two human ova of the pre-villous stage, having an ovulation age of about eleven and twelve days respectively. Contributions Embryology (Carnegie Inst Wash) 29: 127-156.

HODGKIN, A.L. (1992). Chance \& Design: reminiscences of Science in Peace and War; page 68.Cambridge University Press.

HOPKINS, G.M. (1949). Autobiographical memoir in Hopkins and Biochemistry (Eds. Needham J and Baldwin E Heffer) Cambridge, U.K.

JONES, C.J. (2006). Structure of the midterm placenta of the spotted hyena, Crocuta crocuta, with emphasis on the diverse hemophagous regions Cells. Tissues Organs 183: 141-155.

KEYNES, R.D. (2002). Fossils Finches and Fuegians Harper Collins New York. KREBS, H.A. (1967). The making of a scientist. Nature 215: 1441.

LEMBERG, R., BARCROFT, J. and KEILIN, D. (1931). Uteroverdin. Nature 128: 967-968.

MACFARLANE, G. (1979). Howard Florey, OUP Oxford.

MACFARLANE, R.G. and ABRAHAM, E.P. (2004).Howard Walter Florey, Baron Florey 1898-1968: experimental pathologist and bacteriologist. Dictionary of National Biography, Oxford University Press.

MARSHALL, F.H.A. (1922). The Physiology of Reproduction, $2^{\text {nd }}$ edition Longmans Green and Co London.

McCANCE, R.A. and WIDDOWSON, E. (1991). The Chemical Composition of Foods, $5^{\text {th }}$ edition Royal Society of Chemistry London.

MEDAWAR, J. and PYKE, D. (2000). Hitler's Gift; the true story of scientists expelled by the Nazi regime. Richard Cohen books, London.

MESCHIA, G., COTTER, J.R. BREATHNACH, C.S. and BARRON, D.H. (1965).
The Hemoglobin, Oxygen, Carbon Dioxide And Hydrogen lon Concentrations In The Umbilical Bloods Of Sheep And Goats As Sampled Via Indwelling Plastic Catheters. Quart J Expt Physio/50: 185-195.

MESCHIA, G., WOLKOFF, A.S. and BARRON, D.H. (1958). Difference in Electric Potential Across The Placenta Of Goats. Proc Nat/ Acad Sci USA 44: 483-485.

MOSSMAN, H.W. (1991). Classics revisited: Comparative Morphogenesis of the Fetal Membranes and associated Uterine Structures. Placenta 12: 1-5.

NEEDHAM, J. (1931). 'Chemical Embryology' 3 volumes Cambridge, Cambridge University Press.

NEEDHAM, J. (1934). A History of Embryology, Cambridge: Cambridge University Press.

NEEDHAM, J. with others (1955-2004). Science and Civilization in China Vols 17(24 parts) Cambridge University Press.

PEPYS, M.B. (1972). Cambridge University Natural Science Club 1872-1972. Nature 237: 317-319.

QUIGLEY, J.P., BARCROFT, J., ADAIR, G.S. and GOODMAN, E.N. (1937). The difference in potential across gastric membranes and certain factors modifying the potential. Am J Physio/119: 763-767.

ROUGHTON, F.G.W. (1949). Joseph Barcroft. Obituary Notices of Fellows of the Royal Society. 6: 315-345.

SIBLEY, C.P., COAN, P.M., FERGUSON-SMITH, A.C., DEAN, W., HUGHES, J., SMITH, P., REIK, W., BURTON, G.J., FOWDEN, A.L. and CONSTÂNCIA, M. (2004). Placental-specific insulin-like growth factor 2 (Igf2) regulates the diffusional exchange characteristics of the mouse placenta. ProcNat/Acad SciUSA 101: 8204-8208.

SLATER, W.K. and EDWARDS, J. (1965). Sir John Hammond 1889-1964. Biographical Memoirs of Fellows of the Royal Society 11: 100-113

STEVEN, D.H. (Ed), (1975). Comparative placentation: Essays in structure and function. Academic. Press, London, New York.

STREETER, G.L. (1926). The 'Miller' ovum-the youngest normal human embryo thus far known Contributions. Embryology (Carnegie Inst. Wash) 18: 31-48.

VILLEE, C.A. ed (1960). The Placenta and Fetal Membranes Williams and Wilkins.

WEATHERALL, M. and KAMMINGA, H. (1992). Dynamic Science: Biochemistry in Cambridge 1898-1949 Cambridge.

WEATHERALL, M. (2000). Gentleman, Scientists and Doctors: Medicine at Cambridge Boydell Cambridge.

WIDDOWSON, E.M. (1963). The experimental approach to some paediatric problems. Proc. Nutrition Society 22: 121-128

WIDDOWSON, E.M. and McCANCE, R.A. (1963) The effects of finite periods of undernutrition at different ages on the composition and subsequent development of the rat. Proc $R$ Soc Lond B Biol Sci158: 329-342

WINCHESTER, S. (2008). The Man Who Loved China Harper Collins.

YOUNG, I.M. (1992). Classics revisited: Researches on Prenatal Life by Sir Joseph Barcroft. Placenta 13: 607-612. 


\section{Further Related Reading, published previously in the Int. J. Dev. Biol.}

See our recent Special Issue Epigenetics \& Development edited by Saadi Khochbin and Stefan Nonchev at:

http://www.ijdb.ehu.es/web/contents.php?vol=53\&issue=2-3

See Special Issue Pattern Formation edited by Michael K. Richardson and Cheng-Ming Chuong at:

http://www.ijdb.ehu.es/web/contents.php?vol=53\&issue=5-6

Receptor-mediated uptake and transport of macromolecules in the human placenta Henning Schneider and Richard K. Miller

Int. J. Dev. Biol. (2010) 54: 367-375 (doi: 10.1387/ijdb.082773hs)

Placental nutrient supply and fetal growth

Michelle Desforges and Colin P. Sibley

Int. J. Dev. Biol. (2010) 54: 377-390 (doi: 10.1387/ijdb.082765md)

Puzzles of mammalian fertilization - and beyond

J. Michael Bedford

Int. J. Dev. Biol. (2008) 52: 415-426

Biographical memoir on Joseph Needham (1900-1995).

J.B. Gurdon and B. Rodbard (2000).

Int. J. Dev. Biol. 44: 9-13.

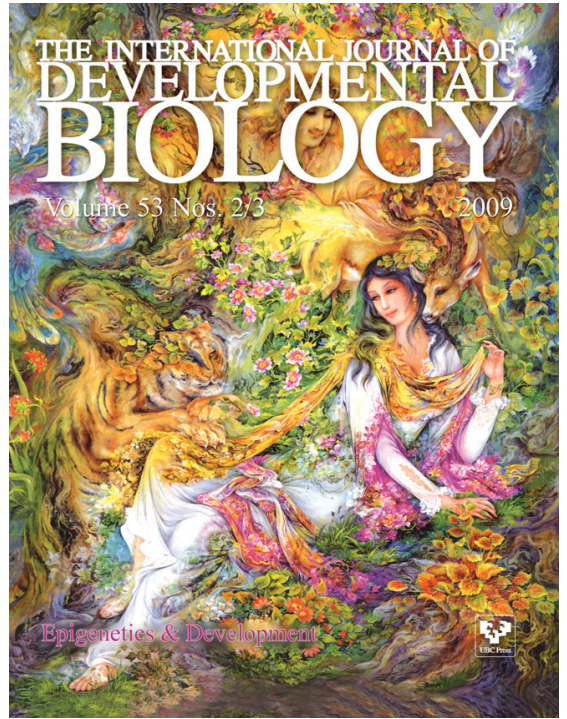

5 yr ISI Impact Factor $(2008)=3.271$
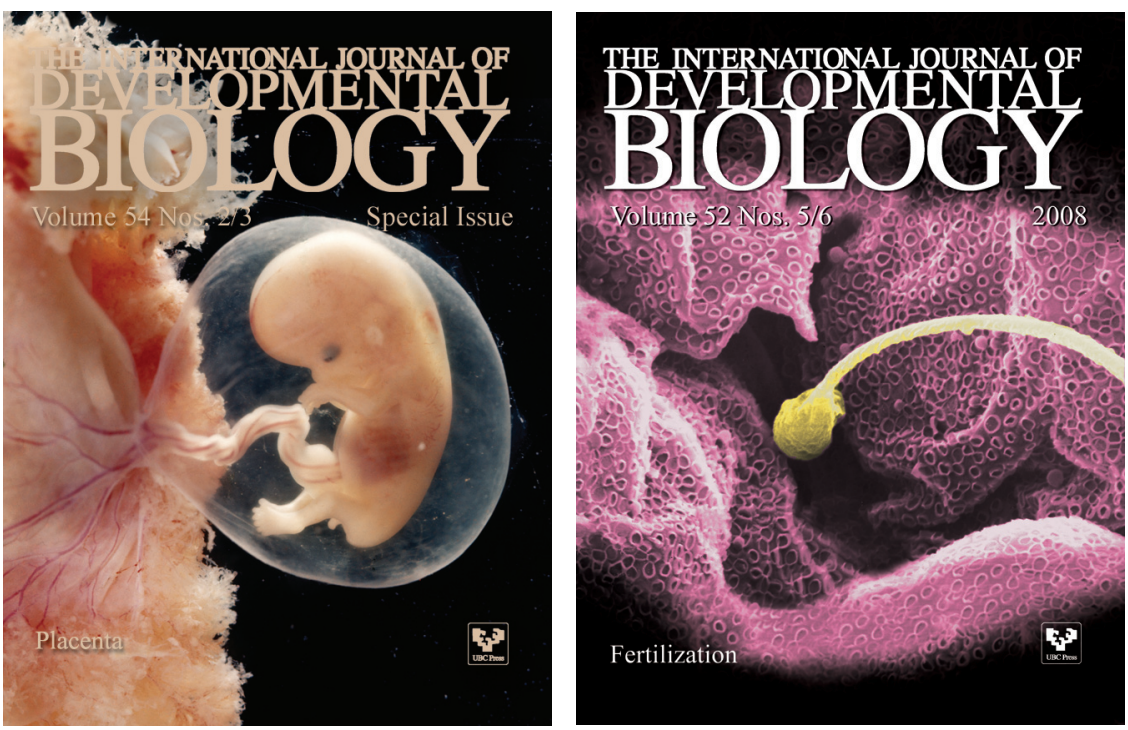